\title{
GIS for groundwater management in cities on volcanoes: example from the Colli Albani Region, Rome, Italy
}

\author{
G. Giordano, R. Mazza, A. Cecili, G. Capelli, D. De Rita, G. Bigi, and S. Rodani \\ Dipartimento di Scienze Geologiche, Universita' degli Studi "Roma Tre", \\ L. go S. Leonardo Murialdo 1, 00146, Roma, Italy
}

\begin{abstract}
The Colli Albani volcanic complex contains the deposits of Quaternary stratovolcano. They cover over $1500 \mathrm{~km}^{2}$ around the city of Rome and have formed one of the most important aquifers for the city since the Roman age. Presently the volcano is quiescent, although it is characterised by shallow seismicity and gas emissions along the main fault systems.

The area has undergone rapid urbanisation during the last 50 years and is presently characterised by intense, diffuse, and uncontrolled water withdrawal. In this paper we document a significant drop of water table, locally up to $100 \mathrm{~m}$, which occurred during the last ten years. During the same period, there occurred several episodes of $\mathrm{CO}_{2}$ release in air that threatened human and animal life. We suggest a possible interplay between the dynamics of the hydrogeological system and the still active hydrothermal system, and present a Geographic Information System designed for the zonation of the area into various 'water-yielding capacity' classes as a function of aquifer depletion, urbanisation, and land use as well as hydrothermal activity and seismicity.
\end{abstract}

\section{INTRODUCTION}

Not many, perhaps, knows that Rome is a city on a volcano, and that its famous urban development as well as epical history of more than 2,000 years depends strictly on the presence of a volcano just a few km SE of the city. The city of Rome has flourished on abundant caldera-forming ignimbrites erupted during the time span between 600,000 and 300,000 years BP from the Colli Albani Volcano, a large Quaternary stratovolcano whose youngest activity has been dated between 100,000 and 20,000 years BP. Presently the volcano is quiescent, although some seismic activities at a shallow depth, local uplift, hydrothermal activity, and gas emissions chiefly along the main fault systems cutting through the volcano are present, and constitute the geological risk for Rome and its metropolitan vicinity.

The Colli Albani area has been the most important and historical water resource for the city of Rome since the Roman age. The volcanic succession overlies a Pliocene claystone aquiclude and can therefore be considered a single aquifer, although the permeability associated with interbedded lavas and pyroclastic rocks is highly variable both laterally and vertically.

The area has undergone rapid urbanisation after World War II, with strong increment of urban and industrial sites, as well as intensive agriculture. Presently the area is characterised by intense, diffuse, and uncontrolled water withdrawal, which has resulted in the over-exploitation and pollution of the water resource. During the last ten years, a significant drop of the water table, locally up to $100 \mathrm{~m}$, has been detected, implying that presently the withdrawal is depleting the strategic reservoir. Furthermore, recent studies suggest a possible interplay between the dynamics of the hydrogeological system and the still active hydrothermal system.

Good management of the water resource today in active and/or recently active volcanic areas needs the implementation of proper tools capable of taking into account the evolution of land use, hydrogeology, and volcanic activity within the geological and structural framework.

We present a Geographic Information System (GIS) implemented for the western sector of Colli Albani, and designed for the zonation of the area in classes of 'wateryielding capacity' as a function of aquifer depletion, urbanisation and land use, and hydrothermal and seismic activity, focussing on the potential risk related to gas emissions induced by the water table drawdown.

\section{COLLI ALBANI VOLCANIC COMPLEX}

The study area is located along the western slope of the Quaternary Colli Albani Volcano, and is also the southern part of the Rome metropolitan area. The geology and structure of this sector of volcano is based on the $1: 10,000$ scale geological survey (Fig. 1) and more than 600 drill holes (De Rita et al. 1995). The Quaternary volcanic succession records the following three distinct epochs of activity.

\section{Epoch I - Tuscolano-Artemisio Eruptive Complex} (600-300 ka)

During this epoch, more than 283 cubic $\mathrm{km}$ of volcanic deposits were emplaced (De Rita et al. 1995). Four main parossistic eruptions emplaced a large volume of tephritic to K-foiditic, pozzolanaceous ignimbrites with low aspect 
ratio, covering an area of more than $1,500 \mathrm{sq} . \mathrm{km}$ around the volcano centre. Many phono-tephritic lava flows were also emplaced mainly after the first ignimbrite eruption, filling tectonically controlled NE-NW trending palaeovalleys (Fig. 1 and 2), which reflect the tectonic trends present in the pre-volcanic substratum. The volcanic succession overlies a Pliocene-middle Pleistocene sedimentary succession (Fig. 2) comprising mainly claystone and sandstone. The morphological relief of the top of the sedimentary succession was investigated from the drill hole and geoelectric data, and they shows valleys at $70 \mathrm{~m}$ below the sea level and ridges at $50 \mathrm{~m}$ above the sea level. A composite caldera ( $10 \mathrm{~km} \mathrm{x10} \mathrm{km} \mathrm{wide)} \mathrm{was} \mathrm{formed} \mathrm{in} \mathrm{the} \mathrm{central} \mathrm{area} \mathrm{of} \mathrm{the}$ volcano as a consequence of large-volume eruptions. In the study area, the NW-trending caldera faults (Fig. 2) have downthrown the volcanic succession by several hundred metres towards the NE.

\section{Epoch II - Faete Eruptive Complex (300-100 ka)}

After the last caldera collapse of the Tuscolano-Artemisio epoch $(338 \mathrm{ka})$, the volcanic activity was concentrated within the collapsed area, wherein the $6 \mathrm{~km}^{3}$ Faete edifice filled the caldera with lavas and strombolian to subplinian pyroclastic products (Fig. 2). A few of the lava flows spilled over the caldera wall (e.g. Capo di Bove lava, $285 \mathrm{ka}$ ) and reached the area presently covered by the city of Rome.

\section{Epoch III - Castelgandolfo Eruptive Complex (100-<20 ka)}

The most recent epoch of volcanic activity is characterised entirely by phreatomagmatic eruptions from eccentric monogenic to coalescing maars, tuff rings, and tuff cones, presently somewhere filled up by lakes (e.g. Lago di Albano). In the area covered by GIS, the phreatomagmatic centres align along the NW-trending caldera faults and $\mathrm{N}$-trending more recent lineaments. This epoch is characterised by a further decrease in the volume of lava erupted and increase in the efficiency of magma-water interaction.

\section{Present-day volcanic activity}

The Colli Albani Volcano is commonly considered inactive. This is because the most recent products have been dated between 37,000 and 11,000 years BP (Fornaseri 1985; Voltaggio et al. 1994). However, the Colli Albani area is characterised by frequent seismic activity, local uplifts, hydrothermal circulations, and gas emissions.

Recent results from three-dimensional techniques of inversion of earthquake wave arrival times in this area suggest the presence of a cooling magma body approximately between 6 and $18 \mathrm{~km}$ beneath the volcano (Cimini et al. 1994; Chiarabba et al. 1994). These authors suggest that the cooling of this body could be the trigger for the frequent
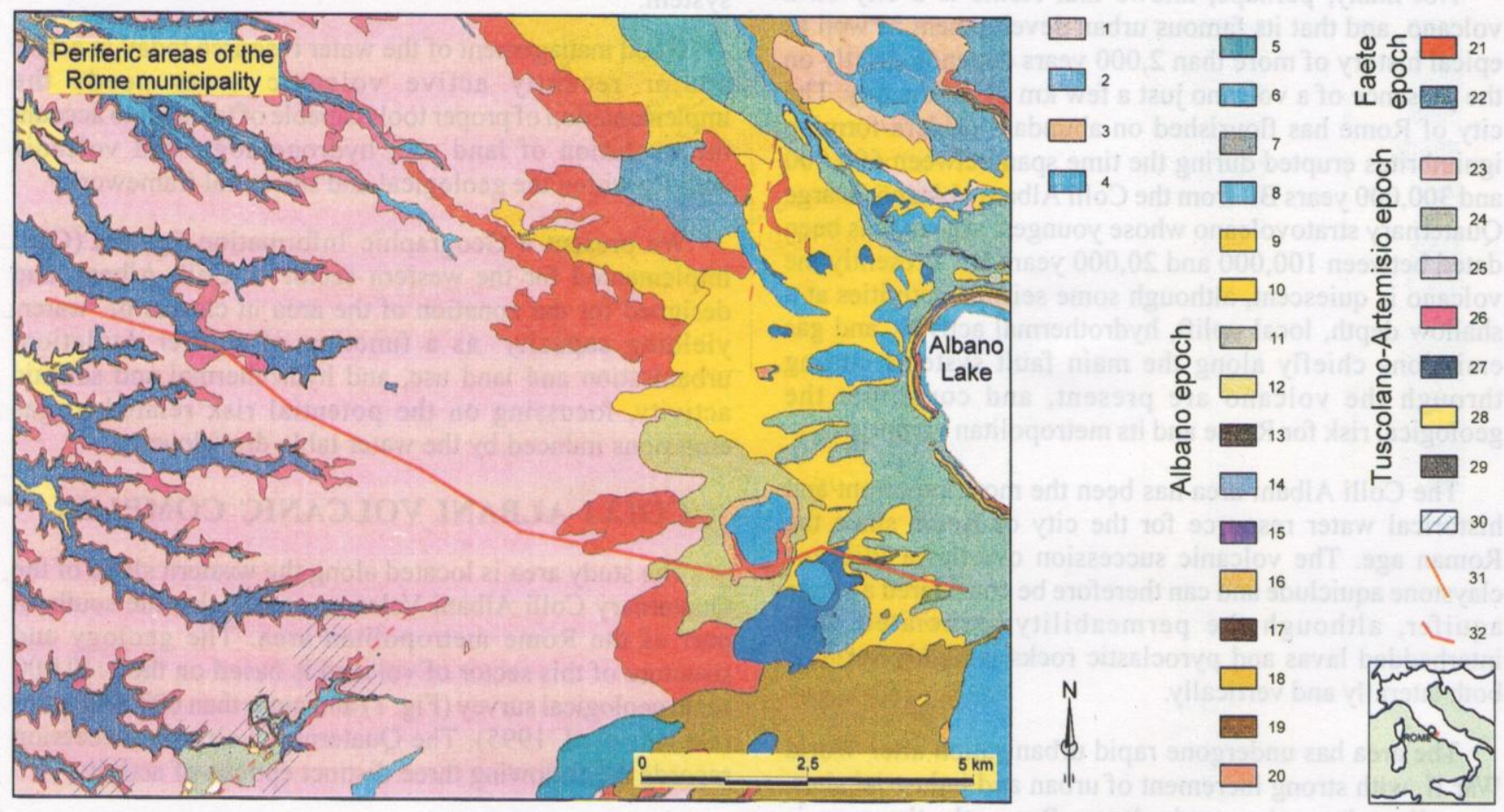

Fig. 1: Geological map of the western part of the volcano. 1: Quarry backfill; 2: Alluvial deposits; 3: Talus; 4: Lacustrine deposits; 5-20: Fine-grained, pheatomagmatic fallout, pyroclastic flow, and lahar deposits from eccentric monogenic and coalescing maars relative to the Albano Epoch (100-<20 ka); 21: Lavas; 22: Scoria cones relative to the Faete Epoch (300-100 ka); 23-29: Pozzolanaceous ignimbrites and reworked deposits relative to the Tuscolano-Artemisio Epoch (600-300 ka); 30: Hydrothermally altered area; 31: Hypothetical fault ; and 32: Hydrogeological cross-section 
shallow seismicity with low or very low magnitude $(<3.5)$ located mostly at depths ranging between 4 and $8 \mathrm{~km}$. The tremors are responsible for the local increase of fluid pressure. Such seismicity represents itself an important element of risk for the city of Rome (Fig. 3). The subsurface of the city is in fact strongly heterogeneous, inducing anomalous amplifications of the seismic waves as a function of the distribution of the structural-stratigraphic units (Salvi et al. 1991; De Rita et al. 1995). A local uplift (related to magma intrusion) of up to $40 \mathrm{~cm}$ has been recorded since the last 45 years (Chiarabba et al. 1997).

The area around Rome is also characterised by hydrothermal and gaseous (mainly $\mathrm{CO}_{2}$ and subordinately $\mathrm{H}_{2} \mathrm{~S}$ ) emanations (Tor Caldara, Solforata, Ardea, Cava dei Selci, Barozze) (Fig. 4) that could be related to a high temperature system in its waning stage. Geochemical anomalies were recorded at the Pozzo Barozze I geochemical station, where the redox potential dropped in correspondence with the 1992 seismic swarms that occurred in the Northern Vulsini area (Quattrocchi et al. 1992). These authors suggested that the geochemical anomalies could be explained by a variation of fluid pressure induced by the extensional stress field variation. This would imply current active interactions between the deep volcanic system and regional tectonics (Quattrocchi et al. 1992; Faccenna et al. 1994). Seismicity and hydrothermal activity indicate that there is still some energy in the volcanic system. Obviously, we are not in a situation like at Vesuvius, but we should consider that the present period of quiescence of the volcano, which was active between 37,000 and 11,000 years BP, is generally comparable with the earlier quiescence periods observed in the chronostratigraphic records of the volcano.

\section{HYDROGEOLOGY}

The Colli Albani Volcano can be considered as a complex hydrogeological unit, which reflects the lateral and vertical variation in the permeability values related to threedimensional architecture of different lithologies (i.e. lavas, coherent and incoherent pyroclastic rocks, and hydrothermally altered rocks) and volcano-tectonic structure (i.e., regional and caldera-related faults). The Pliocene-middle Pleistocene sedimentary succession is the basal aquiclude at a regional scale. The hydrogeology of the area (Capelli et al. 1998) is outlined below.

\section{Intracaldera sector}

It is the upper portion of the volcano and hence the recharge area of the system, which crops out in the Lago di Albano (Fig. 5). This sector is very complex as the caldera wall represents a lithological and reasonably a permeability barrier, and because the volcanic succession is herein several hundred metres thick.

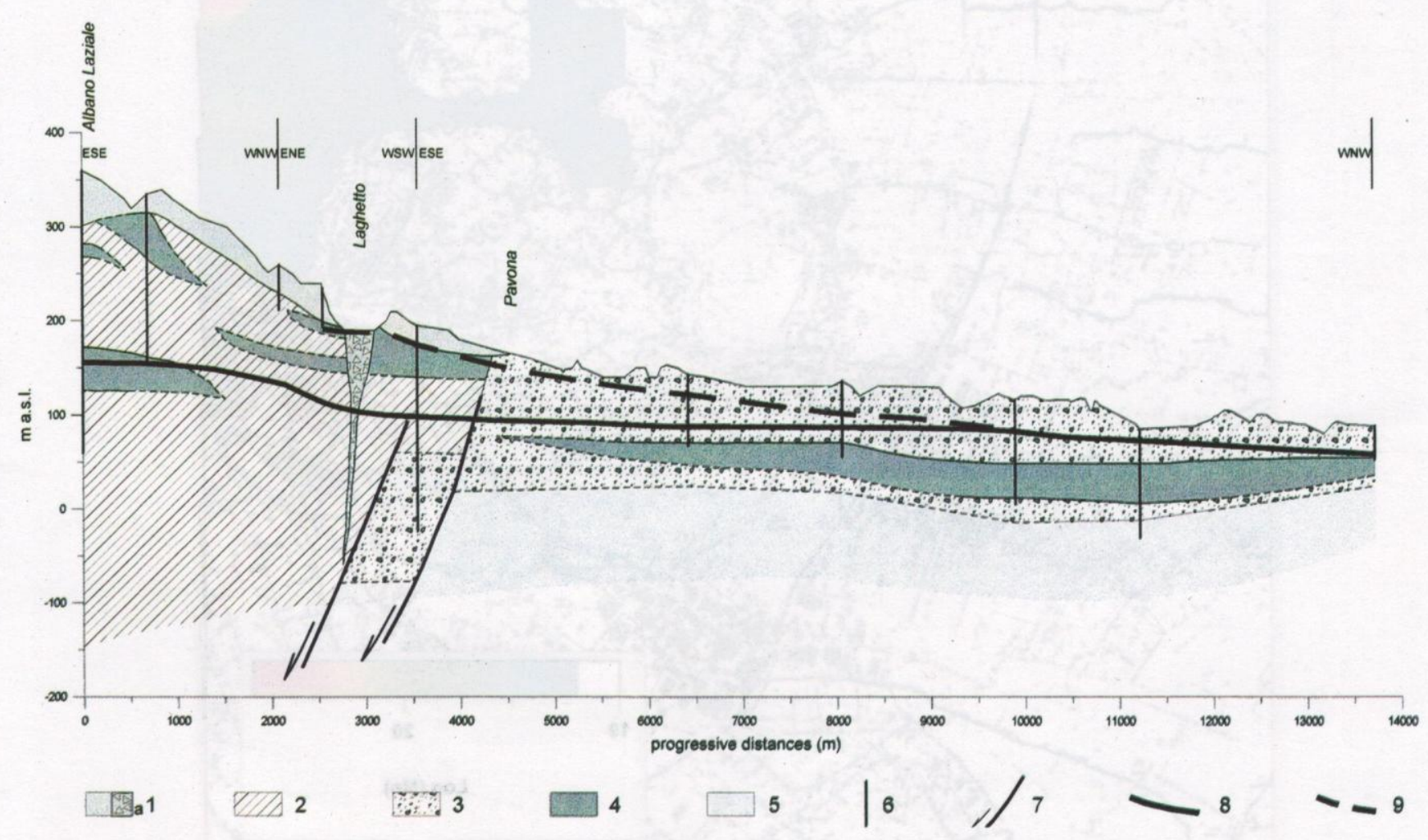

Fig. 2: Geological and hydrological cross-section. 1: Products of the Albano activity a) Conduit breccia; 2: Products of the Faete activity; 3: Ignimbrites of the Tuscolano-Artemisio activity; 4: Lava; 5: Prevolcanic substratum; 6: Well; 7: Fault; 8: 1999 isopiezometric level; and 9: 1972 isopiezometric level. 
Giordano G. et al.

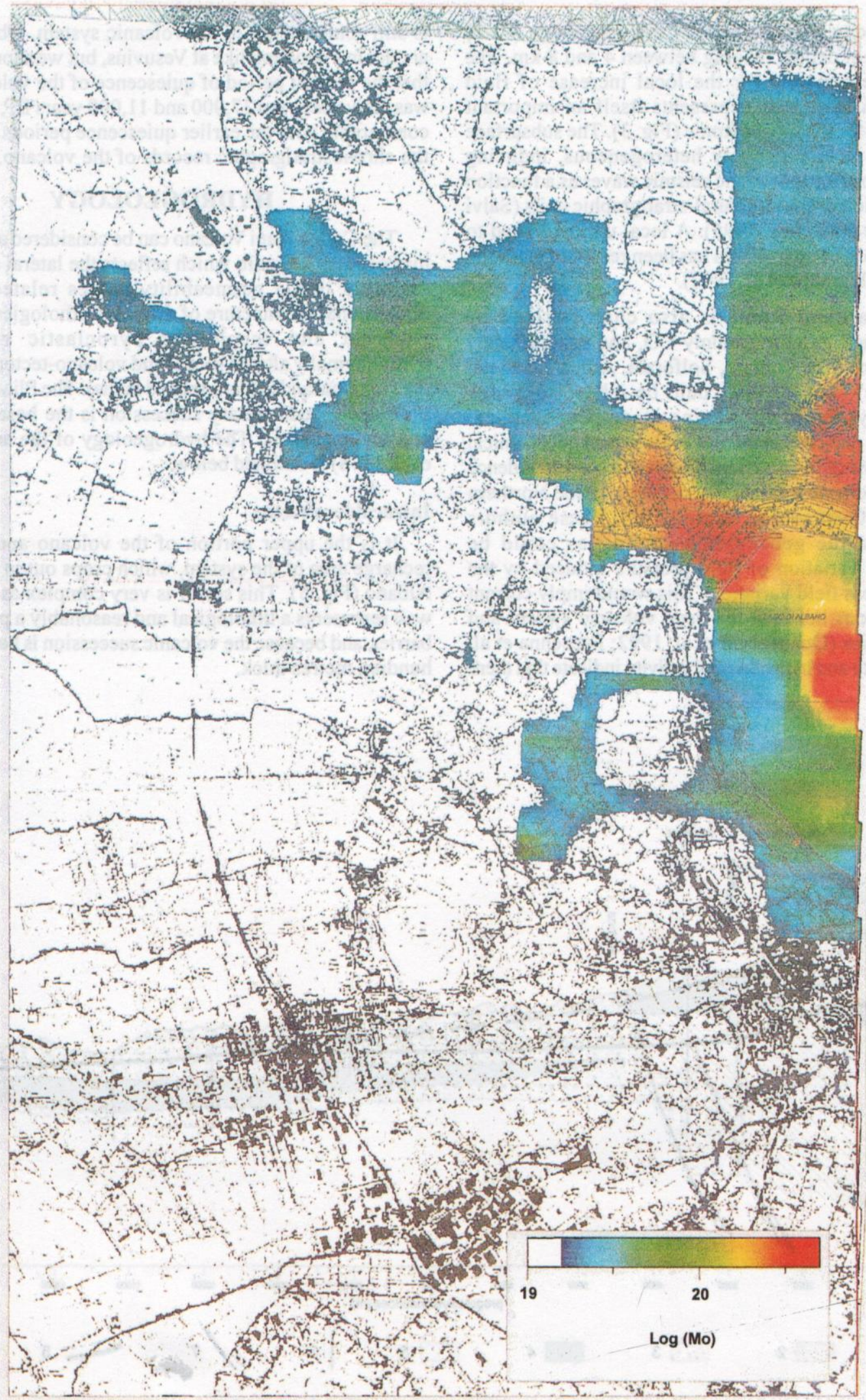

Fig. 3: Seismic moment distribution (logarithmic scale) during the 1989-1990 seismic sequence (after Selvaggi and Caracciolo 1998) 


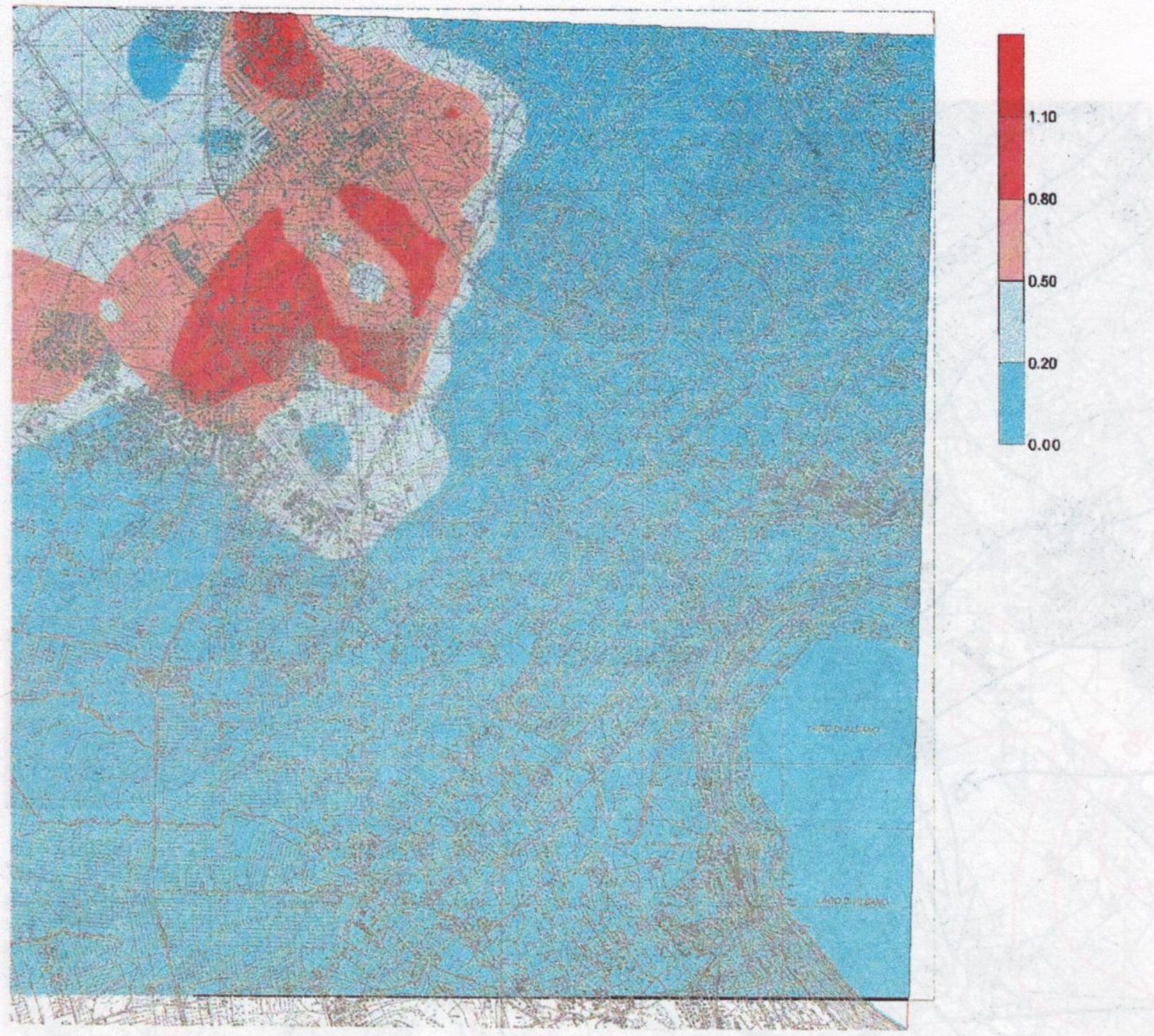

Fig. 4: Partial pressure of $\mathrm{CO}_{2}$ in the groundwater of the study area. Geographic grid: $1 \mathrm{~km}$ by $1 \mathrm{~km}$ for scale in this and next figures; vertical lines indicate the geographic north (after Pizzino et al. 1999)

\section{Extracaldera sector}

It is characterised by radial and centrifugal flow paths with respect to the volcano centre. The three-dimensional lithological variation of volcanic rock bodies allows for locally perched aquifers as well as confined aquifers. In distal areas, several springs as well as rivers cut in the volcanic rocks, and are fed by this aquifer, locally with flow rates up to 1,500 1/s. The piezometric trends reflect the morphological relief of the pre-volcanic aquiclude (Enel 1990), and they favour the concentration of groundwater drainage inside the topographic lows at the top of the pre-volcanic succession, and hence the well yield.

The isopiezometric level (Fig. 5) measured during 1998 (Capelli et al. 1999) shows a relatively uniform seepage from the intracaldera sector towards the extracaldera sector. Since 1972 (Mouton, 1977; Ventriglia 1990), a generalised drawdown of the water table, locally up to $100 \mathrm{~m}$ has been detected (Fig. 6), and it is related to an uncontrolled, unplanned, and accelerated groundwater withdrawal for potable, industrial, agricultural as well as private purposes (Fig. 7). The area has in fact undergone strong urbanisation during the last $\mathbf{5 0}$ years (Fig. 8 and 9), and particularly during the last 20 years. For this reason, the new wells were drilled at greater depths withdrawing deeper aquifer levels, which are also confined at places. Owing to increased industrial and agricultural activities in the area of Pavona-Santa Palomba, the water table has gone down for more than $100 \mathrm{~m}$ (Fig. 2) during the last 10 years, whereas around Lake Albano, the lowering of water table is due to the withdrawal for domestic use. Besides 
Giordano G. et al.
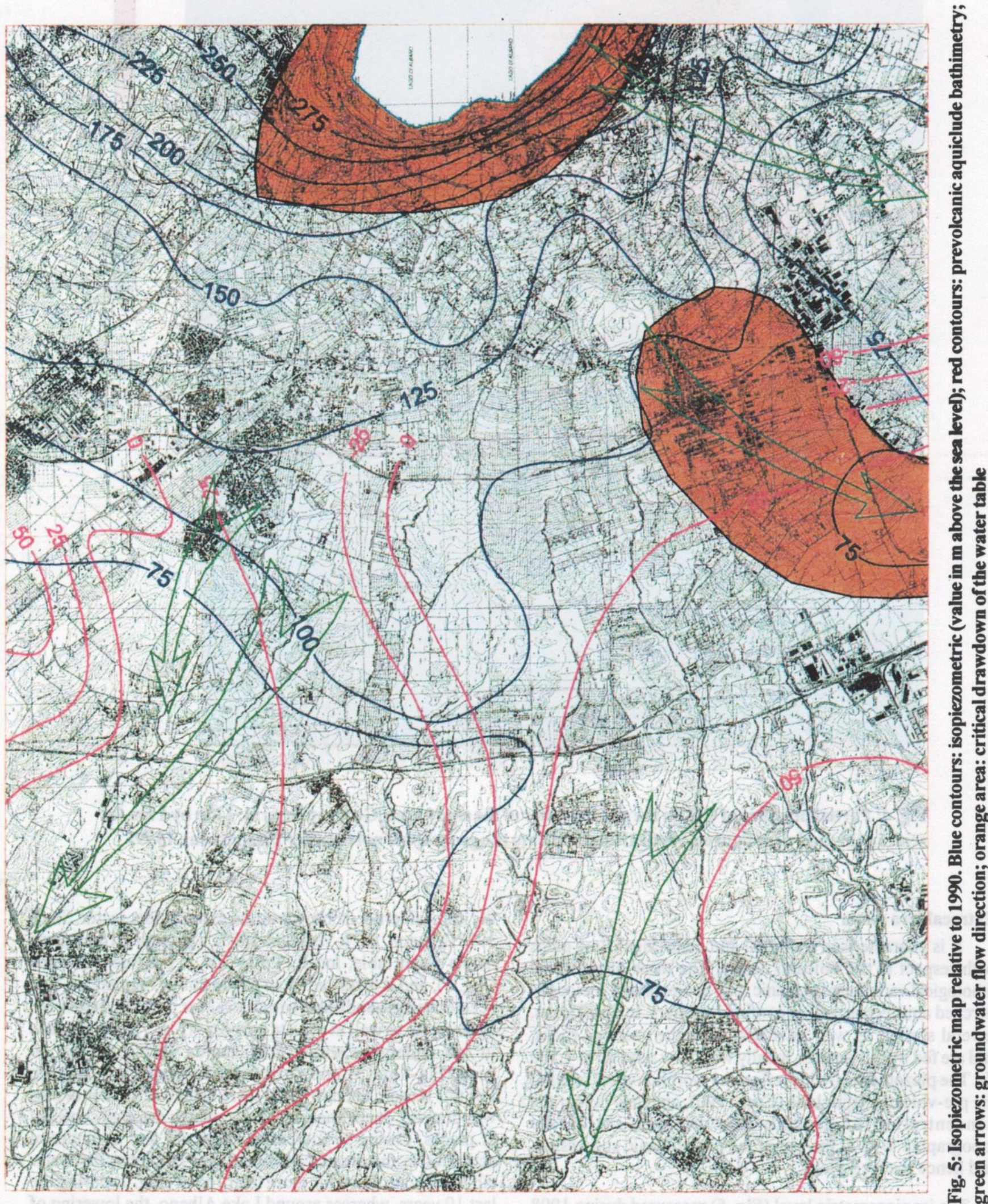


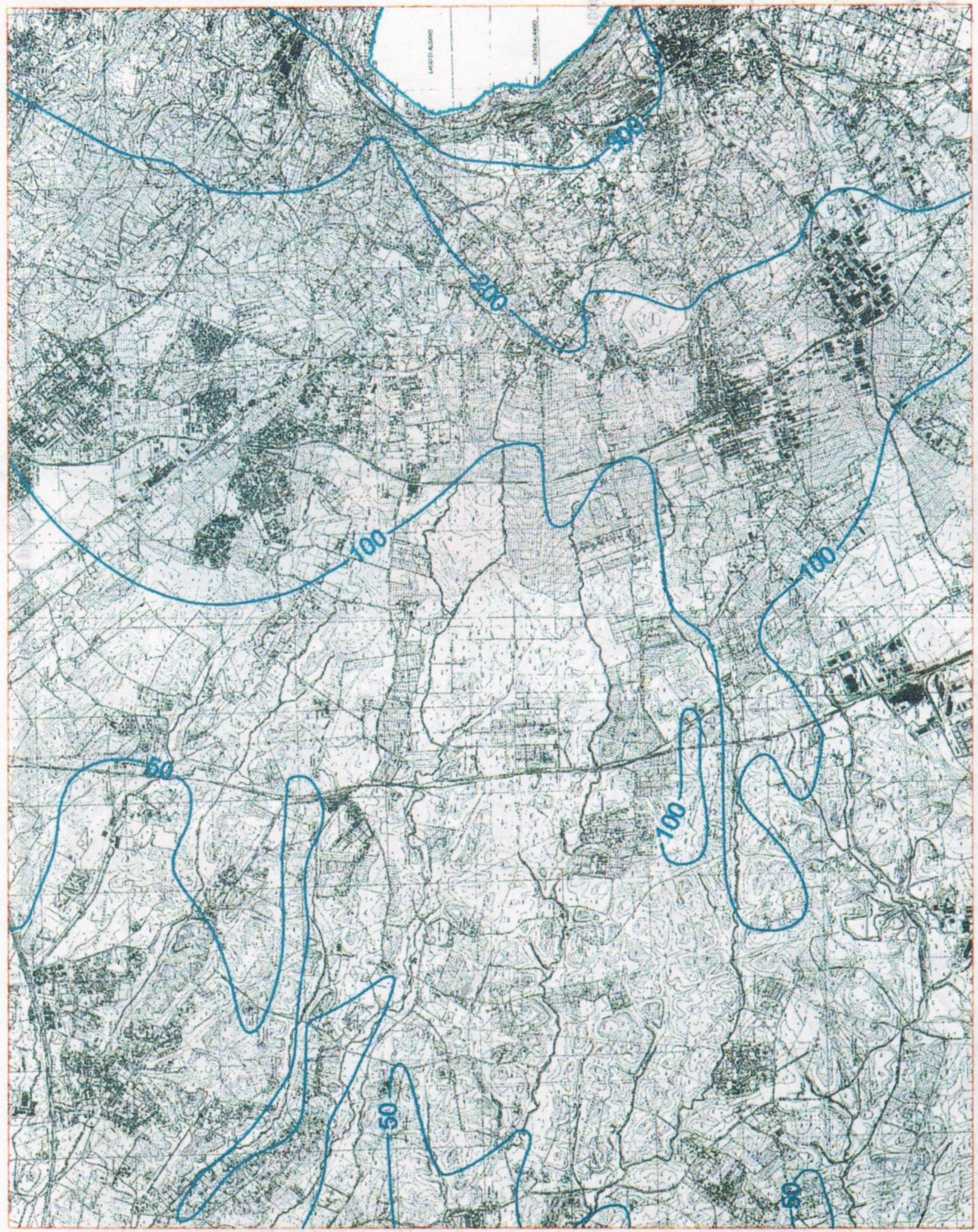


Giordano G. et al.
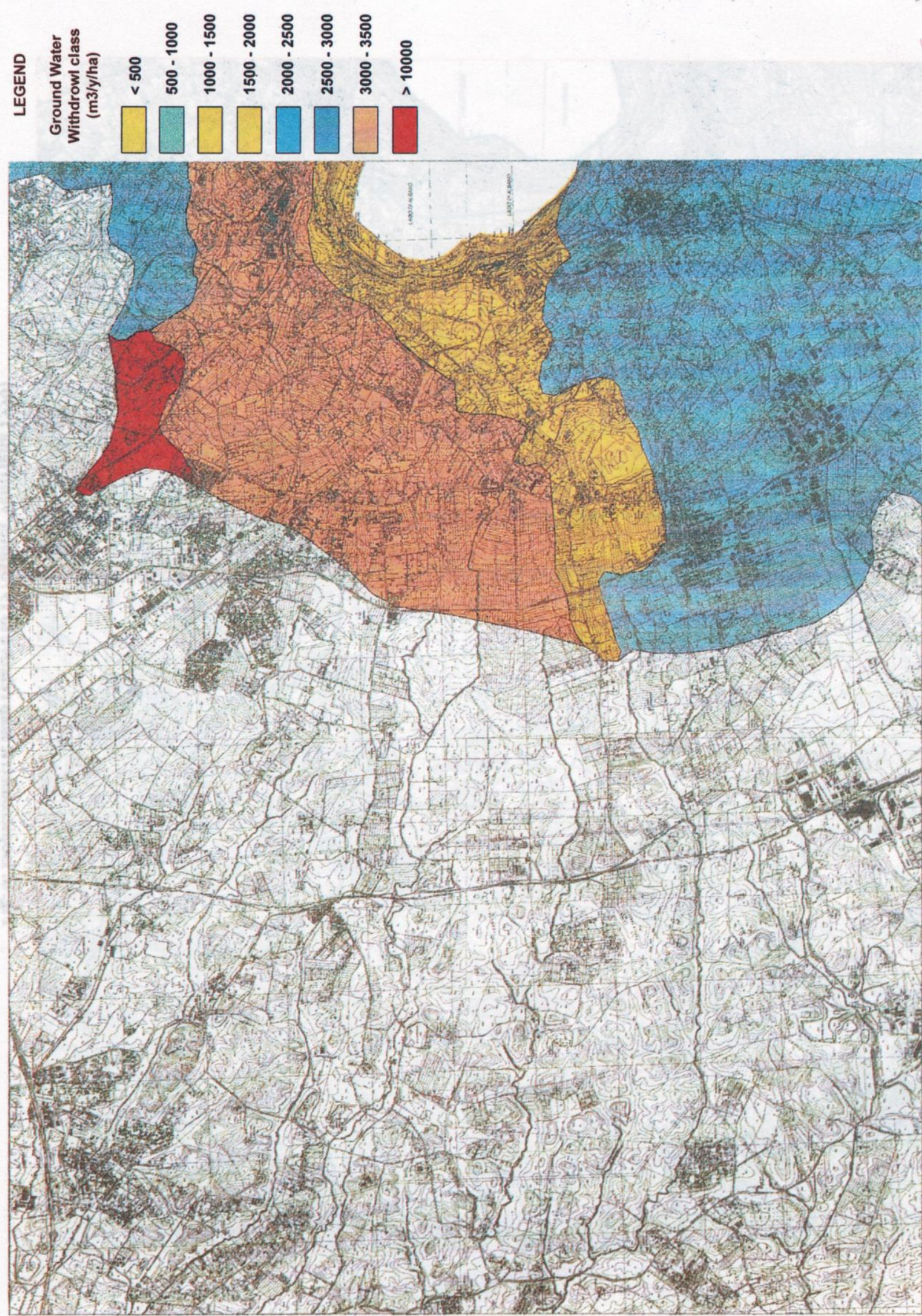


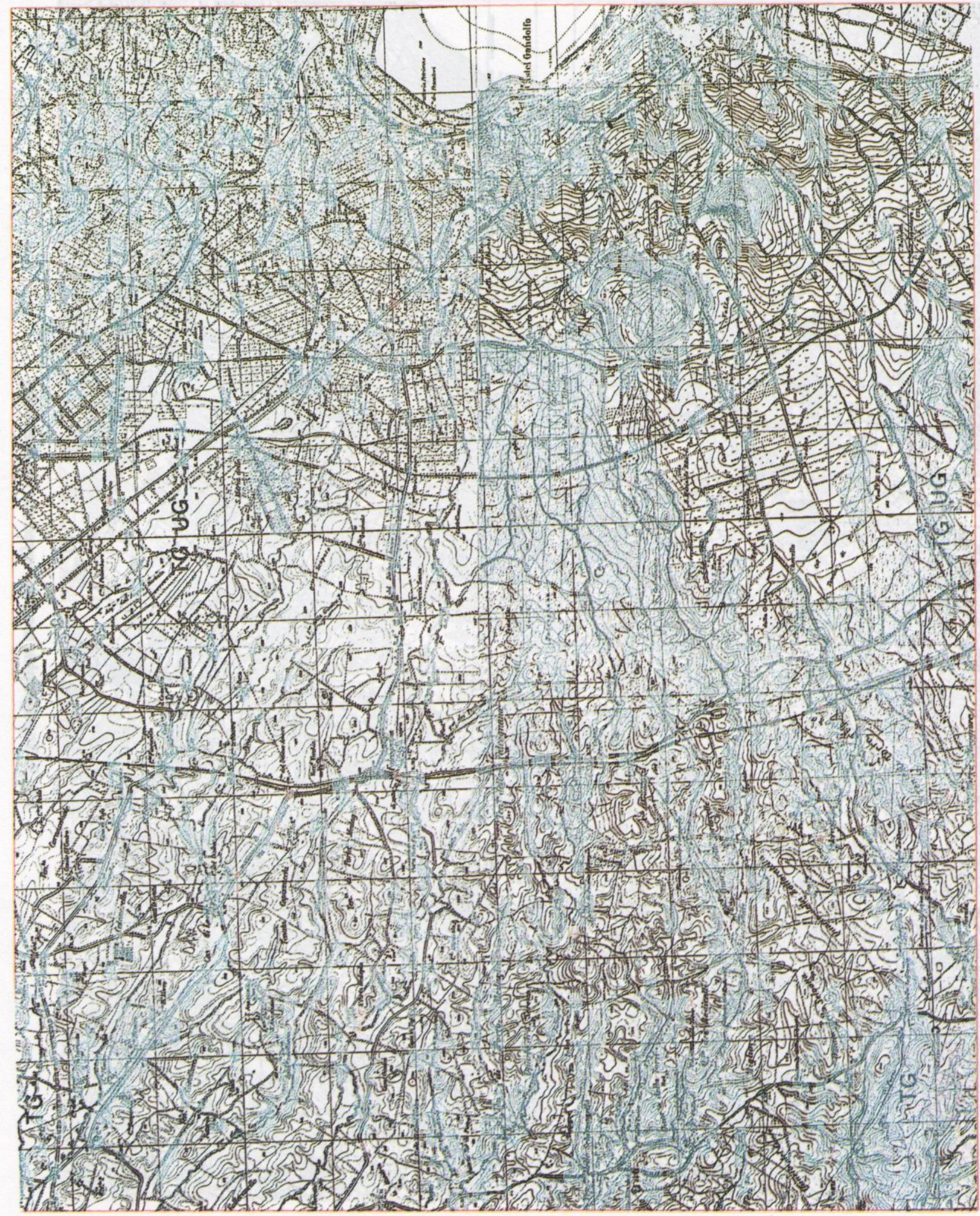


Giordano G. et al.

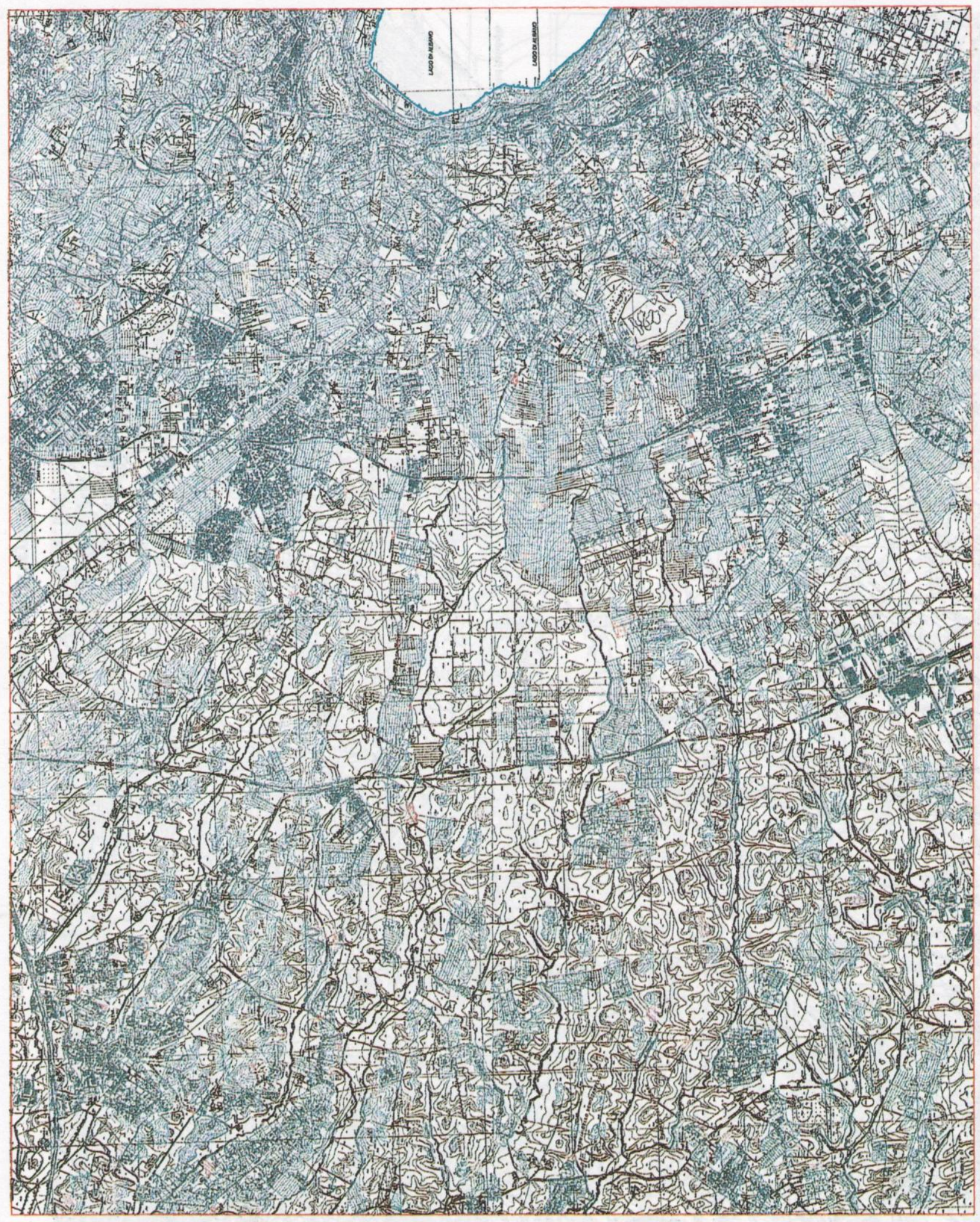


the critical areas of maximum lowering of water table, the aquifers of the Colli Albani Region as a whole have experienced a drawdown of the water table in the order of some tens of metres and strong decompression of the confined aquifers.

\section{DISCUSSIONS AND CONCLUSIONS}

The Colli Albani Volcano can be considered as quiescent with episodes of unrest probably related to a still active plumbing system. $\mathrm{CO}_{2}$ and $\mathrm{H}_{2} \mathrm{~S}$ gas emissions are concentrated in tectonically active areas. $\mathrm{CO}_{2}$ emissions are the most hazardous for human and animal life.

There is a generalised depletion of the regional groundwater resource, with areas where the water table dropped for more than $100 \mathrm{~m}$ in the last 10 years. Groundwater withdrawal for industrial, agricultural, domestic, and private purposes is increasing with time, due to urban development of the Rome metropolitan area. At present, there is no management of the groundwater resource.

The main question arising from the outlined situation is whether or not the depletion of the groundwater resource has an influence on the release of gases in the air. The solubility of gas in water is related to both the lithostatic and hydrostatic pressures at different levels in the subsurface. The consequence is that the drawdown by several tens of metres to more than $100 \mathrm{~m}$ of the water table may reduce consistently the amount of $\mathrm{CO}_{2}$ and other volcanic gases, which can be dissolved in water, hence increasing the potential for gas release in the air. Furthermore, confined aquifers at deeper levels undergo significant decompression as a result of the decrease in hydrostatic pressure exerted on the aquicludes, in turn further decreasing the gas solubility in water. This also promotes the saturation of gas in the groundwater progressively at shallower levels polluting important potable water resources. Geochemists agree that volatiles exolved at depth from the volcanic plumbing system reside at shallower levels confined by permeability barriers and that seismic shocks, both related to the low intensity local seismicity and/or to highly energetic earthquakes often occurring along the Apenninic chain, may trigger the sudden release of large batches of gas (e.g. Quattrocchi et al. 1992). Aquifers represent therefore an important filter to the passage of gas through the upper levels of the crust. The recognition of this role is very important, as the correct management of the groundwater resource should, in our opinion, become one of the parameters to be taken into account when planning human development in volcanic areas. A GIS may be a powerful tool for such a purpose. The preliminary data should lead to the identification of areas of tectonic weakness from the geology of the volcano, seismic activity, and gas emissions. The hydrogeological data should be analysed for temporal comparison of isopiezometric surfaces and for obtaining the three-dimensional geometry of aquifers. This allows for the quantification of the volumes of groundwater lost with time and to compare the effect of such loss with the monitoring of gas emissions with time. A further step is defining the critical limits for the groundwater resource depletion in relation to gas release and groundwater gas pollution. Based on the above data, a map of 'water-yielding capacity' classes is prepared for planning urban development and land use.

\section{ACKNOWLEDGEMENTS}

This work was benefited from discussions and sharing of data and ideas with C. Chiarabba, L. Pizzino, F. Quattrocchi, G. Selvaggi (Istituto Nazionale di Geofisica, Roma), and R. Funiciello, M. Parotto (Università di Roma TRE).

\section{REFERENCES}

Capelli, G., Cecili, A., Derita, D., Giordano, G., and Mazza, R., 1998, "La conoscenza idrogeologica del territorio quale presupposto alla gestione delle risorse idriche: il caso dei Colli Albani", In: contributi tecnico scientifici alla giornata di studio: "Uso e Tutela delle acque sotterranee" Viterbo, 3 aprile 1998 - 31 figg. - Ordine dei Geologi del Lazio Associazione Nazionale di Idrogeologia e Pozzi per Acqua Regione Lazio, Assessorato Opere e Servizi di Reti e mobilità, 52 p.

Capelli, G., Cecili, A., Petitta, M., Montesanti, A., and Salvati, R., 1999, "Studio per la omogeneizzazione, integrazione e ampliamento delle conoscenze idrogeologiche nei domini vulcanici peri-tirrenici del Lazio". "Conferenza di Bacino" Il Piano di bacino per la difesa del suolo; 12-13 febbraio 1999 Castelgandolfo ROMA (CD-ROM version).

Chiarabba, C., Malagnini, L., and Amato, A., 1994, Three dimensional velocity structure and earthquake relocation in the Alban Hills Volcano, Central Italy. Bull. Seismol. Soc. Am., v. 84 , pp. $295-306$.

Chiarabba, C., Amato, A., and Delaney, P. T., 1997, Crustal structure, evolution, and volcanic unrest of the Alban Hills, Central Italy. Bull. Volcano, v. I(59), pp. 161-170.

Cimini, G. B., Chiarabba, C., Amato, A., and Iyer. H. M., 1994, Large teleseismic $\mathrm{P}$-wave residual variation in the Alban Hills Volcano, Central Italy. Annali di geofisica, v. 37, pp. 969-988.

De Rita, D., Faccenna, C., Funiciello, R., and Rosa, C., 1995, Stratigraphy and volcano-tectonics. In Trigila R. ed. The volcano of the Alban Hills, SGS Press, Roma.

Dobran, F., Barberi, F., and Casarosa, C., 1990, Modeling of volcanological processes and simulation of volcanic eruptions. VSG Report 90-01, Giardini Ed., Pisa.

Dobran, F., 1993, Global volcanic simulation of Vesuvius. VSG Report 93-1, Giardini Ed., Pisa, 148 p.

Enel, 1990, "Esplorazione geotermica nel Progetto di Ricerca Colli Albani - Stato delle conoscenze" Enel - Direzione della Produzione e Trasmissione - Vice Direzione Attività Geotermiche - Area Promozione e Sviluppo - Ufficio Esplorazione - Roma Relazione Inedita.

Faccenna, C., Funiciello, R., Montone, P., Parotto, M., and Voltaggio, M., 1994, An example of late Pleistocene strikeslip tectonics: the Acque Albule basin (Tivoli, Latium). Memorie descrittive della carta geologica d'Italia, v. 49, pp. 37-50.

Mouton, J., 1977, "Contributo allo studio delle acque sotterranee dell 'Agro Romano e Pontino". In: Atti del Convegno di Studio "L'acqua per la Pianura Pontina. Situazioni e prospettive. 7 figg., 6 tabb. Latina , 41 p.

Pizzino, L., Galli, G., Guerra, M., Mancini, I. C., Quattrocchi, F., and Scarlato, P., 1999, ${ }^{222} \mathrm{Rn}$ and $\mathrm{CO}_{2}$ in groundwater, soils 
Giordano G. et al.

and indoor throughout the Ciampino - Marino area (Alban Hills Volcano, Central Italy). EGU Congress - Amsterdam.

Quattrocchi, F., Amato, A., Calcara, M., Chiarabba, C., and Funiciello, R., 1992, Anomalie geochimiche correlabili alla sequenza sismica nell'area settentrionale dei M.ti Vulsini (Castel S. Giorgio, Febbraio 1992). Atti Conv. G. N. G. T. S.

Salvi, S., Boschi, E., Di Bona, M., Funiciello, R., Malagnini, L., Marra, F., and Rovelli, A., 1991, Subsurface geology and variations of seismic response in the city of Rome. Fourth international conference on seismic zonation; Stanford. August 25-29, 1991.
Selvaggi, G. and D'Ajello Caracciolo, F., 1998, Seismic deformation at the Alban Hills Volcano during the 1989-1990 seismic sequence. Ann. Geofis., v. 41, pp. 225-231.

Ventriglia, U., 1990, "Idrogeologia della Provincia di RomaRegione vulcanica dei Colli Albani" Amm. Prov. di Roma. Assessorato ai Lavori Pubblici, Viabilità e Trasporti - 220 tabb., 9 figg. 8 Tav. v. III, $547 \mathrm{p}$.

Voltaggio, M., Andretta, D., and Taddeucci, A., 1994, 230Th$238 \mathrm{U}$ data in conflict with $40 \mathrm{Ar} / 39 \mathrm{Ar}$ leucite ages for quaternary volcanic rocks of the Alban Hills, Italy. Eur. J. Mineral., v. 6, pp. 209-216. 